\title{
Faculty members' perceptions towards utilizing blackboard in teaching system at Hafr Al-Batin University, Saudi Arabia
}

\author{
Lobna Khamis Ibrahim*1,2, Asmaa Ghareeb Mohamed ${ }^{2,3}$, Faten Mane Aldhafeeri ${ }^{4}$, Malik Alqdah ${ }^{5}$ \\ ${ }^{1}$ Nursing Administration, Faculty of Nursing, Tanta University, Egypt \\ ${ }^{2}$ College of Applied of Medical Science, University of Hafr Al-Batin, KSA \\ ${ }^{3}$ Community Health Nursing, Faculty of Nursing, Assiut University, Egypt \\ ${ }^{4}$ Radiological Sciences, CAMS University of Hafr Al-Batin, KSA \\ ${ }^{5}$ Electrical Engineering, College of Engineering, University of Hafr Al Batin, KSA
}

Received: December 10, 2018

DOI: 10.5430/jnep.v9n5p64
Accepted: January 10, 2019

Online Published: January 20, 2019

\begin{abstract}
Background and objective: The faculty members' perceptions regarding Blackboard as the pedagogical management tool plays a vital role in learning and teaching process. Aim: To survey the perceptions of faculty members towards utilizing Blackboard in the teaching system at Hafr Al-Batin University.

Methods: Design: Quantitative descriptive design was utilized depending on online surveys. Setting: The study was conducted in all Colleges of Hafr Al-Batin University. Participants: 174 faculty members from different colleges at the University of Hafr Al-Batin. Tools: Questionnaire consisted of two parts; the first includes the faculty demographic information and the second describes faculty perception in four sections; usefulness, enjoyment, satisfaction, and challenges.

Results: The study demonstrated that perceived "usefulness" and "enjoyment" were the most highly mean scores.

Conclusions: The faculty members have a positive attitude towards the implementation of the Blackboard system. Recommendations: A great need for training of both faculty members and students in the Blackboard system regularly.
\end{abstract}

Key Words: E-learning, Learning management process, Blackboard, Faculty members' perception

\section{INTRODUCTION}

Due to the rapid growth of technology, e-learning plays a crucial part of the educational delivery process for empowering students and facilitating the learning process, ${ }^{[1]}$ especially that brought significant changes in the academic environment in the Kingdom of Saudi Arabia (KSA). ${ }^{[2]}$ E-learning is the process of transforming the educational delivery from the traditional modes of learning toward utilization of information communication technologies (ICT) through innovative appli- cations of the Internet in the service of learning or learner support to enhance the learning capabilities. ${ }^{[3]}$

E-learning is the preferred mode of study for many students, not only older ones but also younger learners. It stimulates education by offering a solution to distance, time, and education gaps as well as cost problems. ${ }^{[4,5]}$ E-learning is designed to manage all learning activities, known as Learning Management System (LMS) or Virtual Learning Environments (VLEs) or Course Management Systems (CMSs). ${ }^{[5,6]}$

\footnotetext{
*Correspondence: Lobna Khamis Ibrahim; Email: lobnakhamis2020@ gmail.com; Address: Nursing Administration, Faculty of Nursing, Tanta University, Egypt.
} 
LMS has become a reliable mean in teaching and training in most universities around the world, whether open source (as Moodle or Dokeos) or closed source (as Blackboard or Tutor) ${ }^{[5,7]}$ It encompasses the provision of pedagogical management tools for delivering online teaching and learning activities. ${ }^{[7]}$ Blackboard (Bb) was founded in 1997 that considered as one of the most popular marketable LMSs adopted in higher education institutions. ${ }^{[8]}$ The tools in Bb have the potential to change the way teachers teach and learners learn to meet the individual needs of students. ${ }^{[9]}$

The Bb System is a virtual learning environment and Webbased server software that features course management, customizable open architecture, and scalable design to allow integration with student information systems and authentication protocols. Its main purposes are to add online elements to courses traditionally delivered face-to-face and to develop completely online courses with few or no face-to-face meetings. ${ }^{[10]}$ It should not only be seen as a set of courses made on the websites, but it is rather a set of processes for teaching and learning management. ${ }^{[11]}$

$\mathrm{Bb}$ provides access to online learning services for students, faculty members, and administrators. These services usually include access control provision of learning content, communication tools, and organizations of user groups ${ }^{[12]}$ The communication tools include announcements, discussion, chat, and mail. The announcements help the faculty members to post messages for students. The discussion feature helps faculty members and students to interact frequently through discussion threads and offer feedback. The chat function allows students to converse and share ideas. Finally, the mail allows students to send messages to faculty members or to other groups. ${ }^{[13,14]}$

The learning content includes course content, calendar, learning modules, assessments, assignments, grade book, and the media library. The course content function allows faculty members to post tutorials, labs, tests, quizzes, and videos. The calendar features posts announcements due dates. The learning modules support online classes to post tutorials for students. The assessments function helps students to do their quizzes online and get results. The assignment feature helps students to submit their assignment online. The grade book feature posts grades for students. Finally, media library function posts videos or any other media. ${ }^{[10,13]}$

Grobgeld, Teichman-Weinberg et al. (2016) ${ }^{[15]}$ stated that the faculty members' perception is a range of viewpoints, attitudes, understandings, approaches, or expectations that are related to the status within the organization. On the other hand, the competency level of faculty members directly influences the use of technology for teaching and learning purposes. ${ }^{[16]}$ The above realities show that faculty members' perception on technology integration plays a vital role in successful implementation of blackboard virtual environment in the learning and teaching process. ${ }^{[9]}$ Therefore, faculty members should make the best use of the latest available technology and transfer what they have learned to new generations of students to meet the demands of the 21st-century learner. ${ }^{[5]}$

\subsection{Justification of the study}

In UHB, the $\mathrm{Bb}$ was established since the academic year of 2012/2013 for course delivery and learners' engagement. The faculty members offer a variety of education courses for the undergraduates using traditional learning, on-learning (Bb system) or blended learning (mixed between both). However, until now there are some difficulties interrupt the full usefulness of this system. It is obvious that the faculty members' perception, whether positive or negative towards the use of $\mathrm{Bb}$ in the teaching system may play an important role in customizing students to be a part of the online learning environment. Therefore, the faculty members must recognize both the opportunities and challenges of an effective implementation of the $\mathrm{Bb}$ system.

\subsection{Aim}

The aim of this study is to survey the perceptions of faculty members towards utilizing Blackboard in the teaching system at Hafr Al-Batin University, Kingdom of Saudi Arabia (KSA).

\subsection{Research questions}

Three research's questions were asked about:

(1) What are the perceptions of faculty members at the University of Hafr Al-Batin in terms of utilization of Blackboard in the teaching system?

(2) What are the challenges facing the faculty members at the University of Hafr Al-Batin to use the Blackboard?

(3) Is there a relationship between demographic data of faculty members and their perception?

\section{Methodology}

\subsection{Design}

The current study was utilized a quantitative descriptive design in nature to answer the research's questions. An online survey was used for gathering data that are highly convenient for the assessment of e-learning systems.

\subsection{Setting}

This study was conducted in all Colleges of UHB. The University currently includes nine Colleges (Applied Medical 
Science, Engineering, Computer Science Engineering, Business Administration, Community, Sciences, Education \& Arts) in Hafr Al-Batin city, as well as the University College (in Al-Khafji, Al-Qariyah Al-Olaya, \& Al-Na'erah) located outside the Hafr Al-Batin City.

\subsection{Participants}

There are 210 faculty members who have already activated for $\mathrm{Bb}$ accounts out of 350 who those taught undergraduates' courses at UHB. The sample of the study consisted of (174) faculty members at UHB who were responded and participated in an anonymous online survey that designed to elicit their perception toward use of learning management system $(\mathrm{Bb})$ in teaching system. Most of the participants were females who represented $(62.1 \%)$ out of 174 , while the rest of the sample were males (37.9\%). The inclusion criteria for selection of sampling was at least one year of experience with using the $\mathrm{Bb}$ system.

The technique of data collection: Data were collected using a public link survey. The University chief information officer (Post-master of UHB) sent to the faculty members' list of e-mails with the details of the study (approval of authoritative person, purpose \& survey link) via official University e-mails. In addition, more than three reminders with survey link sent to faculty members.

\subsection{Tools}

A questionnaire was developed by the researchers to explore the faculty members' perceptions regarding the use of $\mathrm{Bb}$ in the teaching system after reviewing the theoretical literature. The statements of the questionnaire contained either positive or negative attitudes towards utilizing $\mathrm{Bb}$. The instrument of the study comprises two parts. The first part involves the participants' demographic information that consists of seven questions: college's name, age, gender, education level, academic ranking, years of teaching experience, and the number of working hours/week.

The second part describes faculty members' perception in four sections; perceived usefulness of $\mathrm{Bb}$ (13 questions), perceived enjoyment (7 questions), perceived satisfaction (9 questions), and perceived challenges (12 questions). The respondents were asked to rate their answers in five points Likert scale that ranged from $5=$ strongly agree to $1=$ strongly disagree.

\subsection{Procedures}

To ensure the validity of the tool, a panel of seven experts from different colleges at UHB was invited for measuring the internal consistency of the tool. Based on the revision of the questionnaire, a pilot study was carried out on 5\% of faculty members at the College of Applied Medical Sciences (excluded from study sampling) for measuring reliability. The estimated time to fill the questionnaire was consumed from 7 to 10 minutes to be answered. The collection period was extended for a period of two months and a half, starting at the mid of March until the end of May 2018. The value of Cronbach's coefficient alpha test was greater than 0.7 and the value of test-retest reliability for nominal data was greater than 0.76 .

\subsection{Ethical consideration}

The approval for conducting the study was taken from the authoritative personnel at the UHB prior to the data collection. Additionally, the participants were informed about the purpose of the research, their involvement in the project was voluntary, and no penalty would arise from withdrawal or nonparticipation. They were informed that their answers would be kept confidentially.

\subsection{Data analysis}

After the completion of the data collection stage, the responses were transformed to SPSS Statistics version 21 for further statistical analysis. Moreover, quantitative variables were described by the Mean, Standard Deviation (SD) and the Range (Maximum-Minimum). Qualitative variables were described by percentages. Analyzed data was done using the Pearson test and Chi-square for measuring correlation. The significance level was stated at $\alpha=0.05$.

\section{RESUltS}

The overall response rate from was around $83 \%$ out of 210 . As regards to the socio-demographic characteristics of the studied sample, Table 1 revealed that most of the participants who responded and fill the electronic questionnaire were represented equally for both Sciences \& University Colleges (21.8\%), followed by Applied medical sciences college (15.5\%), then Arts and Engineering colleges (14.4\%, 12.6\%) respectively. The finding also shows that nearly two-thirds (62.1\%) of the respondents were females and $50 \%$ of them aged between 40-49 years old with mean score $39.5632 \pm$ 6.62226. It was apparent that around two-thirds (66.7\%) of participants hold a doctorate degree, $56.3 \%$ of them were Assistant professors, as well as $48.9 \%$ had $10-20$ teaching years of experiences with mean score $9.5575 \pm 6.44986$. Equal percent of participants (46.6\%) worked less than 10 hours or 10-20 hours per week with mean score $24.3592 \pm 13.95064$. 
Table 1. Personal characteristics of faculty members at UHB

\begin{tabular}{|c|c|c|}
\hline \multirow{2}{*}{ Item } & \multicolumn{2}{|c|}{ Total No. (174) } \\
\hline & No. & $\%$ \\
\hline \multicolumn{3}{|l|}{ College } \\
\hline Applied Medical Sciences & 27 & 15.5 \\
\hline Sciences & 38 & 21.8 \\
\hline Community & 5 & 2.90 \\
\hline Engineering & 22 & 12.6 \\
\hline Education & 11 & 6.30 \\
\hline Preparatory year & 1 & 0.60 \\
\hline Arts & 25 & 14.4 \\
\hline Computer Sciences Engineering & 5 & 2.90 \\
\hline Business Administration & 2 & 1.20 \\
\hline University College & 38 & 21.8 \\
\hline \multicolumn{3}{|l|}{ Gender } \\
\hline Male & 66 & 37.9 \\
\hline Female & 108 & 62.1 \\
\hline \multicolumn{3}{|l|}{ Age groups } \\
\hline $25-29$ & 11 & 6.3 \\
\hline $30-39$ & 63 & 36.2 \\
\hline $40-49$ & 87 & 50.0 \\
\hline $50+$ & 13 & 7.5 \\
\hline Range & \multicolumn{2}{|c|}{$26.00-59.00$} \\
\hline Mean \pm SD & \multicolumn{2}{|c|}{$39.5632 \pm 6.62226$} \\
\hline \multicolumn{3}{|l|}{ Education level } \\
\hline Post-doctor & 2 & 1.1 \\
\hline Doctorate & 116 & 66.7 \\
\hline Master & 47 & 27.0 \\
\hline Baccalaureate & 9 & 5.2 \\
\hline \multicolumn{3}{|l|}{ Academic ranking } \\
\hline Professor & 1 & 0.6 \\
\hline Associate professor & 7 & 4.0 \\
\hline Assistant professor & 98 & 56.3 \\
\hline Lecturer & 68 & 39.1 \\
\hline \multicolumn{3}{|l|}{ Years of Teaching Experience } \\
\hline$>10$ years & 78 & 44.8 \\
\hline $10-20$ years & 85 & 48.9 \\
\hline$<21$ & 11 & 6.3 \\
\hline Range & \multicolumn{2}{|c|}{$1.00-35.00$} \\
\hline Mean \pm SD & \multicolumn{2}{|c|}{$9.5575 \pm 6.44986$} \\
\hline \multicolumn{3}{|l|}{ No. of working hours/week } \\
\hline$>10$ hours/week & 81 & 46.6 \\
\hline 10-20 hours/week & 81 & 46.6 \\
\hline$<20$ hours/week & 12 & 6.9 \\
\hline Range & \multicolumn{2}{|c|}{$6.00-90.00$} \\
\hline Mean \pm SD & \multicolumn{2}{|c|}{$24.3592 \pm 13.95064$} \\
\hline
\end{tabular}

Table 2 illustrates the perceived usefulness of $\mathrm{Bb}$ among faculty members at UHB. In this table, the highest percentage of faculty $(83.8 \%, 83.3 \% \& 82.1 \%)$ perceive $\mathrm{Bb}$ as an effective way to manage an e-learning course, facilitates communica- tion between them \& their students, and provides the ability to send email to students respectively. The majorities of them $(79.8 \%, 77.6 \% \& 72.9 \%)$ respectively perceive that $\mathrm{Bb}$ enhances diversity in modern teaching methods, allows students with course materials e.g. assignments, lecture notes, $\&$ audio/visual aids, as well as provide sufficient guidance for their students during the teaching process. Around two thirds of participants $(67.8 \%, 66.7 \%, 65.5 \%, \& 62.1 \%)$ perceive that $\mathrm{Bb}$ motivates students to increase practice for their teaching process, provides them with opportunity to acquire knowledge, allows them the opportunities to receive the same classroom information in the familiar environment of the internet and motivate instructors to increase their efficiency of teaching. Moreover, $58.1 \%$ of respondents perceive $\mathrm{Bb}$ as a provider for the necessary experience to teach various ecourses. While, $(67 \% \& 66.7 \%)$ of faculty members perceive that $\mathrm{Bb}$ does not allow them to meet the students' learning needs, and does not encourage students to manage their time wisely.

Table 3 describes the perceived enjoyment among faculty members at UHB. It is noteworthy that $77.8 \%, 70.7 \%$, and $70.3 \%$ of faculty respectively agree that $\mathrm{Bb}$ depends on computer-based interactions, helps them to track student usage of courses, and encourages innovation in the application of information and communication technology. In addition, $69.4 \%$ and $60.9 \%$ of participants suggested that $\mathrm{Bb}$ helps instructors to develop their technical skills in the field of computers and considered it as an interesting method for teaching respectively. While, $72.6 \%$ and $63.2 \%$ of them respectively disagree that $\mathrm{Bb}$ encourages instructors to improve the teaching skills and effectiveness of the quality of education, or gives a greater magnitude for lessons.

Table 4 indicates the perceived satisfaction among faculty members at UHB. As evidenced from data analysis, the highest percent $(72.6 \% \& 70.1 \%)$ of faculty perceive that $\mathrm{Bb}$ is not an easy e-learning system to use and does not save time or effort for faculty members respectively. Moreover, $67.7 \%$ of them decide that $\mathrm{Bb}$ does not give more satisfaction for students in the teaching process. Slightly more than half $(53.7 \%)$ of participants mentioned, that $\mathrm{Bb}$ frustrates instructors to improve their teaching skills and $51.2 \%$ of them document that $\mathrm{Bb}$ frustrates students to improve their learning skills. While $51.2 \%$ of respondents decide that $\mathrm{Bb}$ does not build self-confident to facilitate learning, $44.9 \%$ of them suggest that $\mathrm{Bb}$ does not give them more satisfaction in the teaching process; and only $42.6 \%$ of them decide that $\mathrm{Bb}$ does not save time and effort for students. 
Table 2. Perceived usefulness of blackboard among faculty members at UHB

\begin{tabular}{|c|c|c|c|c|c|c|c|c|c|c|c|}
\hline \multicolumn{2}{|c|}{ Statement } & \multicolumn{2}{|c|}{$\begin{array}{l}\text { Strongly } \\
\text { agree }\end{array}$} & \multicolumn{2}{|c|}{ Agree } & \multicolumn{2}{|c|}{ Neutral } & \multicolumn{2}{|c|}{ Disagree } & \multicolumn{2}{|c|}{$\begin{array}{l}\text { Strongly } \\
\text { Disagree }\end{array}$} \\
\hline & & No. & $\%$ & No. & $\%$ & No. & $\%$ & No. & $\%$ & No. & $\%$ \\
\hline 1) & $\begin{array}{l}\text { Blackboard is an effective way to manage an } \\
\text { e-learning course. }\end{array}$ & 50 & 29.1 & 94 & 54.7 & 18 & 10.3 & 6 & 3.5 & 6 & 3.5 \\
\hline 2) & $\begin{array}{l}\text { Blackboard motivates instructors to increase their } \\
\text { efficiency of teaching. }\end{array}$ & 48 & 27.6 & 60 & 34.5 & 34 & 19.5 & 23 & 23.2 & 9 & 5.2 \\
\hline 3) & $\begin{array}{l}\text { Blackboard provides the necessary experience to } \\
\text { teach various e-courses. }\end{array}$ & 49 & 28.2 & 52 & 29.9 & 46 & 26.4 & 12 & 6.9 & 15 & 8.6 \\
\hline 4) & $\begin{array}{l}\text { Blackboard enhances diversity in modern teaching } \\
\text { methods. }\end{array}$ & 55 & 31.8 & 83 & 48 & 24 & 13.9 & 4 & 2.3 & 7 & 4.0 \\
\hline 5) & $\begin{array}{l}\text { Blackboard provides sufficient guidance for their } \\
\text { students during the teaching process. }\end{array}$ & 60 & 35.3 & 64 & 37.6 & 34 & 20 & 6 & 3.5 & 6 & 3.5 \\
\hline 6) & $\begin{array}{l}\text { Blackboard learning system allows the instructor to } \\
\text { meet the students' learning needs. }\end{array}$ & 6 & 3.5 & 10 & 5.8 & 42 & 24.3 & 57 & 32.9 & 59 & 34.1 \\
\hline 7) & $\begin{array}{l}\text { Blackboard facilitates communication between } \\
\text { instructors and their students. }\end{array}$ & 44 & 25.3 & 101 & 58.0 & 17 & 7.8 & 5 & 2.9 & 7 & 4.0 \\
\hline 8) & $\begin{array}{l}\text { Blackboard motivates students to increase practice } \\
\text { for their teaching process. }\end{array}$ & 60 & 34.5 & 58 & 33.3 & 36 & 20.7 & 10 & 5.7 & 10 & 5.7 \\
\hline 9) & $\begin{array}{l}\text { Blackboard provides students with the opportunity } \\
\text { to acquire knowledge. }\end{array}$ & 64 & 36.8 & 52 & 29.9 & 36 & 20.7 & 12 & 6.9 & 10 & 5.7 \\
\hline 10) & $\begin{array}{l}\text { Blackboard allows students opportunities to receive } \\
\text { the same classroom information in the familiar } \\
\text { environment of the internet. }\end{array}$ & 64 & 36.8 & 50 & 28.7 & 31 & 17.8 & 13 & 7.5 & 16 & 9.2 \\
\hline 11) & $\begin{array}{l}\text { Blackboard allows students with course materials } \\
\text { (e.g. assignments, lecture notes \& audio/visual aids). }\end{array}$ & 44 & 25.3 & 91 & 52.3 & 13 & 7.5 & 19 & 10.9 & 7 & 4 \\
\hline 12) & $\begin{array}{l}\text { Blackboard provides the ability to send email to } \\
\text { individual students, to groups of students, or to all } \\
\text { students. }\end{array}$ & 45 & 26 & 97 & 56.1 & 20 & 11.6 & 6 & 3.5 & 6 & 3.5 \\
\hline 13) & $\begin{array}{l}\text { Blackboard encourages students to use their time } \\
\text { management wisely. }\end{array}$ & 12 & 6.9 & 11 & 6.3 & 35 & 20.1 & 61 & 35.1 & 55 & 31.6 \\
\hline
\end{tabular}

Table 3. Perceived enjoyment among faculty members at UHB

\begin{tabular}{|c|c|c|c|c|c|c|c|c|c|c|c|}
\hline \multirow{2}{*}{\multicolumn{2}{|c|}{ Statement }} & \multicolumn{2}{|c|}{$\begin{array}{l}\text { Strongly } \\
\text { agree }\end{array}$} & \multicolumn{2}{|c|}{ Agree } & \multicolumn{2}{|c|}{ Neutral } & \multicolumn{2}{|c|}{ Disagree } & \multicolumn{2}{|c|}{$\begin{array}{l}\text { Strongly } \\
\text { Disagree }\end{array}$} \\
\hline & & & & & & & & & & & \\
\hline 14) & Blackboard is an interesting method for teaching. & $\begin{array}{l}\text { No. } \\
51\end{array}$ & $\begin{array}{l}\% \\
29.3\end{array}$ & $\begin{array}{l}\text { No. } \\
55\end{array}$ & $\begin{array}{l}\% \\
31.6\end{array}$ & $\begin{array}{l}\text { No. } \\
34\end{array}$ & $\begin{array}{l}\% \\
19.5\end{array}$ & $\begin{array}{l}\text { No. } \\
16\end{array}$ & $\begin{array}{l}\text { \% } \\
9.2\end{array}$ & $\begin{array}{l}\text { No. } \\
18\end{array}$ & $\begin{array}{ll}\% \\
10.3\end{array}$ \\
\hline 15) & Blackboard gives a greater magnitude for lessons. & 13 & 7.6 & 16 & 9.2 & 35 & 20.1 & 64 & 36.8 & 46 & 26.4 \\
\hline 16) & $\begin{array}{l}\text { Blackboard depends on computer-based } \\
\text { interactions. }\end{array}$ & 65 & 38 & 68 & 39.8 & 26 & 15.2 & 3 & 1.8 & 9 & 5.3 \\
\hline 17) & $\begin{array}{l}\text { Blackboard helps instructors to track student } \\
\text { usage of courses. }\end{array}$ & 53 & 30.5 & 70 & 40.2 & 28 & 16.1 & 12 & 6.9 & 11 & 6.3 \\
\hline 18) & $\begin{array}{l}\text { Blackboard encourages innovation in the } \\
\text { application of information and communication } \\
\text { technology. }\end{array}$ & 58 & 33.7 & 63 & 36.6 & 34 & 19.8 & 9 & 5.2 & 10 & 5.8 \\
\hline 19) & $\begin{array}{l}\text { Blackboard helps instructors to develop their } \\
\text { technical skills in the field of computers. }\end{array}$ & 52 & 30.1 & 68 & 39.3 & 37 & 21.4 & 9 & 5.2 & 8 & 4.6 \\
\hline 20) & $\begin{array}{l}\text { Blackboard encourages instructors to improve the } \\
\text { teaching skills and effectiveness of the quality of } \\
\text { education. }\end{array}$ & 7 & 4.1 & 9 & 5.2 & 33 & 19.2 & 58 & 33.7 & 67 & 38.9 \\
\hline
\end{tabular}


Table 4. Perceived satisfaction among faculty members at UHB

\begin{tabular}{|c|c|c|c|c|c|c|c|c|c|c|c|}
\hline \multirow{2}{*}{\multicolumn{2}{|c|}{ Statement }} & \multicolumn{2}{|c|}{$\begin{array}{l}\text { Strongly } \\
\text { agree }\end{array}$} & \multicolumn{2}{|c|}{ Agree } & \multicolumn{2}{|c|}{ Neutral } & \multicolumn{2}{|c|}{ Disagree } & \multicolumn{2}{|c|}{$\begin{array}{l}\text { Strongly } \\
\text { Disagree }\end{array}$} \\
\hline & & No. & $\%$ & No. & $\%$ & No. & $\%$ & No. & $\%$ & No. & $\%$ \\
\hline 21) & Blackboard is easy e-learning system to use. & 7 & 4.1 & 9 & 5.2 & 33 & 19.2 & 58 & 33.7 & 76 & 38.9 \\
\hline 22) & $\begin{array}{l}\text { Blackboard gives more satisfaction for the } \\
\text { instructors in the teaching process. }\end{array}$ & 54 & 31 & 17 & 9.8 & 25 & 14.4 & 53 & 30.5 & 25 & 14.4 \\
\hline 23) & $\begin{array}{l}\text { Blackboard gives more satisfaction for students in } \\
\text { the teaching process. }\end{array}$ & 13 & 7.5 & 10 & 5.8 & 34 & 19.7 & 69 & 39.9 & 48 & 27.8 \\
\hline 24) & $\begin{array}{l}\text { Blackboard builds self-confident to facilitate } \\
\text { learning. }\end{array}$ & 27 & 15.5 & 14 & 8 & 44 & 25.3 & 52 & 29.9 & 37 & 21.3 \\
\hline 25) & Blackboard saves time and effort for students. & 35 & 20.1 & 27 & 15.5 & 38 & 21.8 & 45 & 25.9 & 29 & 16.7 \\
\hline 26) & $\begin{array}{l}\text { Blackboard saves time and effort for faculty } \\
\text { members. }\end{array}$ & 20 & 11.5 & 10 & 5.7 & 22 & 12.6 & 58 & 33.3 & 64 & 36.8 \\
\hline 27) & $\begin{array}{l}\text { Blackboard engages the learners more than other } \\
\text { forms of learning. }\end{array}$ & 28 & 16.1 & 11 & 6.3 & 23 & 13.2 & 54 & 31 & 58 & 33.3 \\
\hline 28) & $\begin{array}{l}\text { Blackboard frustrates students to improve their } \\
\text { learning skills. }\end{array}$ & 41 & 23.6 & 48 & 27.6 & 45 & 25.9 & 15 & 8.6 & 25 & 14.4 \\
\hline 29) & $\begin{array}{l}\text { Blackboard frustrates instructors to improve their } \\
\text { teaching skills. }\end{array}$ & 67 & 34.7 & 33 & 19 & 46 & 26.4 & 18 & 10.3 & 1 & 0.6 \\
\hline
\end{tabular}

Table 5 displays the perceived challenges among faculty members at UHB. As displayed in this table, $73.5 \%$ \& 70.2\% of faculty members respectively agree that $\mathrm{Bb}$ requires special training for instructors and they do not have enough time to be expert users, while $69.5 \%$ of them disagree that $\mathrm{Bb}$ utilization needs support from the college's administration. In addition, $52.3 \%$ of them perceive that $\mathrm{Bb}$ options had not restricted to particular operating systems. Furthermore, $47.1 \%, 43.4 \%$ \& $40.8 \%$ of participants agree that $\mathrm{Bb}$ requires special training for students, harder to learn than expected and unfamiliar way for instructors to transmit information respectively. Equal percent $(38.5 \%)$ of respondents agree that $\mathrm{Bb}$ lacks learning environment and lacks immediate feedback from instructors to students or vice versa. It is worth noting that only $37.4 \%$ of faculty members are not motivated to use $\mathrm{Bb}$ and $35.1 \%$ of them agree that using the $\mathrm{Bb}$ system makes students anxious about their learning. While about one third (33.9\%) of them had neutral responses regarding students' anxious about their learning due to using the $\mathrm{Bb}$ system.

Figure 1 represents the perception of faculty members towards utilizing $\mathrm{Bb}$ in the teaching system. Accordingly, the ranking of the four mean values stated that usefulness of $\mathrm{Bb}$ (4.0385) was perceived as the highest factor for utilizing in teaching system, followed by faculty members' enjoyment (4.00), then challenges for implementation (3.9583). Finally, faculty members' satisfaction with $\mathrm{Bb}$ was perceived as the least factor (3.5556) for utilizing in teaching system.

Table 6 displays the relationship between the perception of faculty members and their socio-demographic characteristics at UHB. The results indicated the existence of statistically significant differences between perceived usefulness of $\mathrm{Bb}$ with female gender (Chi. $=87.185 \& p=.000)$ and educational level $(r=-0.151 \& p=.047)$. There are statistical significant differences between perceived enjoyment of $\mathrm{Bb}$ with female gender (Chi. $=95.111 \& p=.000)$ and years of teaching experience $(r=0.165 \& p=.030)$. Furthermore, a statistically significant difference was found between the perceived challenges of $\mathrm{Bb}$ and female gender $(\mathrm{Chi} .=66.537$ $\& p=.000)$.

Table 7 represents the correlation between subscales of Blackboard perception among faculty members at UHB. It revealed statistically significant correlations between all subscales of $\mathrm{Bb}$ perception among faculty members at the level of (0.01); except for perceived challenges with satisfaction.

\section{Discussion}

Currently, the $\mathrm{Bb}$ learning environment is one of the most educational systems, which used globally and specifically in Saudi University helping in Blended learning. It is one of the solutions useful not only for the students but also for the instructors during the teaching-learning process. However, still many faculty members view technology in the teachinglearning process as a supplementary tool, not as an essential component of success that must be followed. Additionally, the University policy of UHB has made it mandatory that all faculty members utilize the LMS (Bb) in their teaching-learning process and communication with their students. 
Therefore, it is worthwhile to survey the perceptions of fac- UHB, KSA.

ulty members towards utilizing $\mathrm{Bb}$ in the teaching system at

Table 5. Perceived challenges among faculty members at UHB

\begin{tabular}{|c|c|c|c|c|c|c|c|c|c|c|}
\hline \multirow[t]{2}{*}{ Statement } & \multicolumn{2}{|c|}{$\begin{array}{l}\text { Strongly } \\
\text { agree }\end{array}$} & \multicolumn{2}{|c|}{ Agree } & \multicolumn{2}{|c|}{ Neutral } & \multicolumn{2}{|c|}{ Disagree } & \multicolumn{2}{|c|}{$\begin{array}{l}\text { Strongly } \\
\text { Disagree }\end{array}$} \\
\hline & No. & $\%$ & No. & $\%$ & No. & $\%$ & No. & $\%$ & No. & $\%$ \\
\hline $\begin{array}{l}\text { Blackboard system is harder to learn than } \\
\text { expected. }\end{array}$ & 46 & 26.6 & 29 & 16.8 & 33 & 19.1 & 44 & 25.5 & 22 & 12.7 \\
\hline $\begin{array}{l}\text { Blackboard requires special training for } \\
\text { instructors. }\end{array}$ & 74 & 42.5 & 54 & 31 & 30 & 17.2 & 13 & 7.5 & 3 & 1.7 \\
\hline Blackboard requires special training for students. & 0 & 0.0 & 82 & 47.1 & 43 & 24.7 & 33 & 19 & 16 & 9.2 \\
\hline $\begin{array}{l}\text { Blackboard utilization needs support from the } \\
\text { college’s administration. }\end{array}$ & 11 & 6.4 & 14 & 8.2 & 30 & 17.5 & 53 & 31 & 66 & 38.5 \\
\hline $\begin{array}{l}\text { Blackboard is an unfamiliar way for instructors to } \\
\text { transmit information. }\end{array}$ & 0 & 0.0 & 71 & 40.8 & 55 & 31.6 & 38 & 21.8 & 10 & 5.7 \\
\hline $\begin{array}{l}\text { Blackboard takes extra time to respond to } \\
\text { students’ questions. }\end{array}$ & 0 & 0.00 & 63 & 36.2 & 63 & 36.2 & 43 & 24.7 & 5 & 29 \\
\hline Instructors are not motivated to use blackboard. & 0 & 0.00 & 65 & 37.4 & 49 & 28.2 & 46 & 26.4 & 14 & 8.0 \\
\hline $\begin{array}{l}\text { Instructors do not have enough time to be expert } \\
\text { users of Blackboard. }\end{array}$ & 73 & 42 & 49 & 28.2 & 43 & 24.7 & 8 & 4.6 & 1 & 0.6 \\
\hline Blackboard lacks the learning environment. & 0 & 0.0 & 67 & 38.5 & 46 & 26.4 & 46 & 26.4 & 15 & 8.6 \\
\hline $\begin{array}{l}\text { Blackboard lacks immediate feedback from } \\
\text { instructors to students or vice visa. }\end{array}$ & 0 & 0.00 & 67 & 38.5 & 51 & 29.3 & 46 & 26.4 & 10 & 5.7 \\
\hline $\begin{array}{l}\text { Blackboard options may be restricted to } \\
\text { particular operating systems. }\end{array}$ & 0 & 0.00 & 42 & 24.1 & 41 & 23.6 & 63 & 36.2 & 28 & 16.1 \\
\hline $\begin{array}{l}\text { Using the Blackboard system makes students } \\
\text { anxious about their learning. }\end{array}$ & 0 & 0.00 & 61 & 35.1 & 59 & 33.9 & 48 & 27.6 & 6 & 3.4 \\
\hline
\end{tabular}

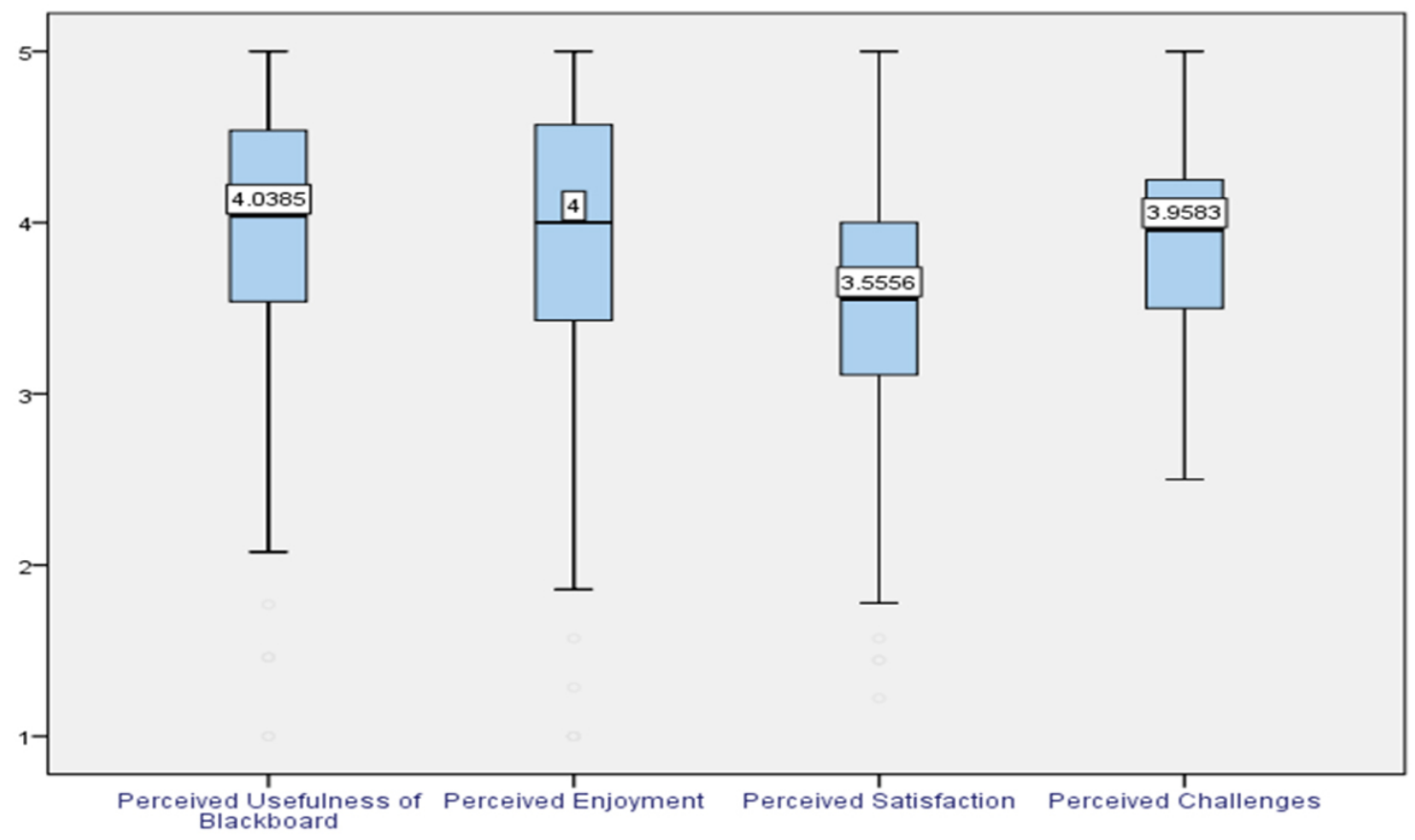

Figure 1. The perception of faculty members towards utilizing blackboard in teaching system 
Table 6. Relationship between perception of faculty members and their sociodemographic characteristics at UHB

\begin{tabular}{|c|c|c|c|c|c|}
\hline \multirow{2}{*}{\multicolumn{2}{|c|}{ Variables }} & \multicolumn{4}{|c|}{ Perception of Faculty Members Towards Blackboard } \\
\hline & & \multirow{2}{*}{$\begin{array}{l}\text { Perceived } \\
\text { Usefulness } \\
28.909\end{array}$} & \multirow{2}{*}{$\begin{array}{l}\begin{array}{l}\text { Perceived } \\
\text { Enjoyment }\end{array} \\
28.818\end{array}$} & \multirow{2}{*}{$\begin{array}{l}\text { Perceived } \\
\text { Satisfaction } \\
28.818\end{array}$} & \multirow{2}{*}{$\begin{array}{l}\begin{array}{l}\text { Perceived } \\
\text { Challenges }\end{array} \\
27.939\end{array}$} \\
\hline \multirow{4}{*}{ Gender } & Chi-square & & & & \\
\hline & Sig. (2-tailed) & .417 & .091 & .091 & .085 \\
\hline & Chi-square & 87.185 & 95.111 & 66.537 & 35.481 \\
\hline & Sig. (2-tailed) & $.000^{* * *}$ & $.000^{* * *}$ & $.000^{* * *}$ & .080 \\
\hline \multirow{2}{*}{ Age groups } & Pearson Correlation & .058 & .109 & .060 & .123 \\
\hline & Sig. (2-tailed) & .446 & .150 & .429 & .107 \\
\hline \multirow{2}{*}{ Education level } & Pearson Correlation & -.151 & 137 & 100 & .094 \\
\hline & Sig. (2-tailed) & $.047 *$ & .071 & 188 & .218 \\
\hline \multirow{2}{*}{ Academic ranking } & Pearson Correlation & 136 & 122 & 095 & .090 \\
\hline & Sig. (2-tailed) & .073 & .109 & .213 & .235 \\
\hline \multirow{2}{*}{ Years of Teaching Experience } & Pearson Correlation & .112 & .165 & .052 & .099 \\
\hline & Sig. (2-tailed) & .140 & $.030^{*}$ & .495 & .194 \\
\hline \multirow{2}{*}{ No. of working hours/week } & Pearson Correlation & .019 & .006 & .051 & .025 \\
\hline & Sig. (2-tailed) & .803 & .941 & .507 & .740 \\
\hline
\end{tabular}

${ }^{*} p<.05 ; * * * p<.001$.

Table 7. Correlation between subscales of blackboard perception among faculty members at UHB

\begin{tabular}{|c|c|c|c|c|}
\hline \multirow{2}{*}{ Variables } & & \multicolumn{3}{|c|}{ Perception of Faculty Members Towards Blackboard } \\
\hline & & Perceived Usefulness & Perceived Enjoyment & Perceived Satisfaction \\
\hline \multirow{2}{*}{ Perceived Usefulness } & Pearson Correlation & & & \\
\hline & Sig. (2-tailed) & & & \\
\hline \multirow{2}{*}{ Perceived Enjoyment } & Pearson Correlation & $.811 * *$ & & \\
\hline & Sig. (2-tailed) & .000 & & \\
\hline \multirow{2}{*}{ Perceived Satisfaction } & Pearson Correlation & $.736 * *$ & $.701^{* *}$ & \\
\hline & Sig. (2-tailed) & .000 & .000 & \\
\hline \multirow{2}{*}{ Perceived Challenges } & Pearson Correlation & $.182 *$ & $.200 * *$ & .098 \\
\hline & Sig. (2-tailed) & .016 & .008 & .200 \\
\hline
\end{tabular}

${ }^{*} p<.05 ; * * p<.01$.

In this study, the results indicated that both faculty members and students might benefit from using $\mathrm{Bb}$ in the teaching system. The faculty members suggested that their potential benefits from $\mathrm{Bb}$ include using an effective way to manage an e-learning course, providing the necessary experience to teach various e-courses, enhancing diversity in modern teaching methods, and facilitating communication between them \& their students. Additionally, the faculty members mentioned that the students' potential benefits from $\mathrm{Bb}$ include providing sufficient guidance during teaching process, motivating to increase practice for teaching process, allowing with course materials, as well as allowing them the opportunities to acquire knowledge and to receive the same classroom information in the familiar environment of the internet.

Undoubtedly, these findings focused that the faculty members' accept the usefulness of $\mathrm{Bb}$ in the teaching system. These findings are in line with Cheok, Wong et al. (2017) ${ }^{[11]}$ who mentioned that many of the teachers appreciated virtual learning environment (VLE) in helping them to make their teaching job easier than the traditional approach, organize their teaching and learning materials, saving their time when updating or locating specific materials and being easy to use.

While the faculty members of the current study suggested that, the $\mathrm{Bb}$ does not motivate them to increase their efficiency of teaching or allow them to meet the students' learning needs. These findings may be due to faculty members' lack of needed training and experience in using Bb, lack of internet signal that interrupts teaching process and restricted rules that obligate them to develop their technological skills in producing electronic materials. On the other hand, the faculty members mentioned that $\mathrm{Bb}$ does not encourage students to use their time management wisely. This means that the participants in this study also claim that students are one of the factor constraints against their utilization of the sys- 
tem. The reason for this result may be due to the students' preference to get lecture notes when they needed instead of getting them posted on $\mathrm{Bb}$.

Additionally, the faculty members may think that the students were not interested in using the Bb system.

Most of the faculty member who are enjoying in using $\mathrm{Bb}$ mentioned that it is an interesting method for teaching, depends on computer-based interactions, tracks student usage of courses, encourages innovation in the application of ICT, and develops technical skills in the field of computers. At the same time, the faculty members reported that $\mathrm{Bb}$ does not encourage improving the teaching skills and effectiveness of the quality of education, and does not give a greater magnitude for lessons. In fact, the faculty members just know the basic skills to use a computer that is not enough, but they must have sufficient knowledge about $\mathrm{Bb}$ and be confident in their skills. These results rationalized as many of faculty members do not have the motivation or time to become expert users of $\mathrm{Bb}$. Furthermore, most of the participants were not familiar with $\mathrm{Bb}$ environment, accustomed to using traditional methods of teaching and unwilling to use Bb. Accordingly, Christie and Jurado (2009) ${ }^{[17]}$ displayed that the faculty member needs to be convinced with the value of learning management systems.

The research concluded by Meajel and Sharadgah (2017) ${ }^{[18]}$ revealed that the faculty members had feared from using of technology and some of them arrived to be a phobia, therefore they needed for empowerment by offering many opportunities. In this aspect, Zaki and Zawaidy (2014) ${ }^{[19]}$ highlighted that the instructors are more familiar with transmitting information with face to face interaction and are less familiar with creating computer-based interactions such as synchronous or asynchronous discussions or creating quizzes with feedback for each answer and may need time to develop different ways of working within technological systems.

From the analysis of findings, faculty members agreed that $\mathrm{Bb}$ does not build self-confident or saves time and effort for both students \& faculty members, as well as does not engage the learners more than other forms of learning. Faculty members also reported that $\mathrm{Bb}$ is difficult to use than expected, and might cause dissatisfaction for them and their students. In addition, $\mathrm{Bb}$ might cause frustration for them and their students. These results can be explained that $\mathrm{Bb}$ is inflexible in use, therefore it may cause dissatisfaction among faculty members and their students especially if they do not receive technical support and training enough. In fact, faculty members are busy with many academic and administrative tasks besides working in $\mathrm{Bb}$. These results are in congruence with Bradford, Porciello et al. (2007) ${ }^{[20]}$ who found that although $\mathrm{Bb}$ was promoted as an easy-to-use system, there is a learning curve that precludes full and timely utility. Guhlin $(1996)^{[21]}$ concluded that most teachers wanted to learn how to use educational technology effectively, but they lack the time, access, and support necessary to do so.

Based on these findings, the researchers stated the challenges faced faculty members are lack of special training for both instructors and students, not enough time to be expert users, harder to learn than expected, unfamiliar way to transmit information, as well as lacks of learning environment and lack of immediate feedback from instructors to students or vice versa. More than one-third of faculty members documented that $\mathrm{Bb}$ has not motivated them to be used and make students' anxious about their learning. The large percentage of neutral responses indicates that about one-third of participants are not aware as to whether or not their students' anxious due to using Blackboard, and this finding indirectly may be due to a limited interaction between faculty and their students through virtual learning environment.

On contrary, Cheok, Wong et al. (2017) ${ }^{[11]}$ confirmed that administrative support is one of the most important obstacles for using $\mathrm{Bb}$ especially by looking into critically needed facilities, such as a reliable and fast Internet connection and providing enough computers for all students. Administrators need to play a more active role in creating conditions fostering innovation. Additionally, Al-Senaidi, Lin et al. (2009) ${ }^{[23]}$ observed that administration and technical support acted as a major challenge to the faculty members' use of computer technology.

In this aspect, Zaki and Zawaidy (2014) ${ }^{[19]}$ found that the obstacles faced by a faculty member using the $\mathrm{Bb}$ may vary among universities depending on the training and technology efficiency, and evaluation of blended learning involves in evaluation on classroom lecturing, virtual teaching, and blended discussion. Every university has its own evaluation system for classroom lecturing. Moreover, Asiri, Mahmud et al. (2012) ${ }^{[16]}$ focused that the instructors in Saudi Arabian educational institutions faced several barriers that inhibited them to use of technology, more specifically in the form of organizational, technological, and personal barriers.

One of the main results of this study is that "perceived usefulness" and "perceived enjoyment" were the most highly mean scores identified faculty members' perception towards utilization of $\mathrm{Bb}$ among the four categories of perception in this study. The perceived challenges category came as a third important factor, while the perceived satisfaction category ranked at the lower end.

The results showed that there is a negative statistical signifi- 
cant difference between the perceived usefulness of Blackboard and educational level of faculty members. This means that the score of perceived usefulness reduced with an increase in qualifications. This finding is logical, the faculty members' who had a bachelor degree perceived the stronger usefulness of $\mathrm{Bb}$ because they are more competencies and skills in technology. This result was inconsistent with that reported by Al-Naibi, Madarsha et al. (2015) ${ }^{[22]}$ who suggested that although the younger generations may have the confidence to use technology in general, nevertheless, they are new to $\mathrm{Bb}$ and thus may not possess the specific skills for using it in an effective way.

Additionally, positive statistical significant differences between perceived enjoyment of Blackboard and with years of teaching. This means that the years of teaching experience was also influenced in terms of the positive outlook of Bb perceived enjoyment in which faculty members who had more teaching experience had a stronger perception than those who had been teaching experience for less than 10 years. While this finding is incongruent with Alghamdi and Bayaga $(2016)^{[7]}$ who evident from their findings that the younger generation who could be anticipated to adopt a more positive attitude towards LMS usage in more of their teaching-related activities than the older generation, rather have a greater measure of negative attitudes.

Finally, the female gender was also noted as being strongly affected regarding the perceived satisfaction and enjoyment of $\mathrm{Bb}$. This result contradicts with Cheok, Wong et al. $(2017)^{[11]}$ who showed that female staff generally perceive IT in the instructional process as less useful and more challenging to use and that the behavioral intention to use e-learning system is lower than that exhibited by their male counterparts. Another research conducted by (Asiri, Mahmud et al. 2012) ${ }^{[16]}$ who argued that although both male and female display the same level of competence and positive beliefs toward the benefits of using computers, men somewhat utilized technology more frequently than women.

Based upon this study's findings, there are highly statistically significant correlations among all subscales of perceived $\mathrm{Bb}$ utilization in teaching system except the perceived satisfaction with perceived challenges. Really, most of the faculty members are dissatisfied with countered challenges of $\mathrm{Bb}$. When answering questions about the challenges of $\mathrm{Bb}$ system, faculty members revealed that it is harder to learn, plus lack of time and special training impediments to be satisfied with teaching on virtual learning environment.

\section{Research limitation}

This study involved only one University that limits the generalizability of research findings due to the low response Published by Sciedu Press rate on the survey instrument in which the target population was limited to faculty members at UHB. In consequences, the result of the study may not reflect the general use of Blackboard.

\section{Conclusion}

The findings of this study concluded that faculty members have a positive attitude toward the implementation of a blackboard system. Thus, the future of Blackboard learning system is promising as a pedagogical management tool in teaching and learning process. Moreover, the findings indicated that the faculty members' accept the utilization of Blackboard for both faculty and students; however, it is still underutilized by faculty members. The participants also claim that students may be one of the factor constraints against their utilization of the system. The results also revealed that there are many challenges faced faculty members.

\section{Recommendations}

Based on path analysis of findings, the researchers recommend the following necessities:

- Training for both faculty members and students about the Blackboard system must be increased and implemented regularly.

- Needing for future research exploring attitudes and practice of faculty members in different universities or in all the universities within the Kingdom.

- Disseminating the culture of virtual learning environment among faculty members and students as a printed brochure, or providing an electronic booklet about the use of Blackboard on University website.

- Improving the efficiency of network connectivity in order to encourage the usage of the Bb system among the faculty and enhance the technical skills.

- Offering rewards to motivate faculty members for better productivity and higher performance through recognition, certificate of appreciation, fewer schedules, relieve workload or renew the contract for foreigners and considered point in the annual evaluation.

\section{ACKNOWLEDGeMENTS}

Researchers express their deep sincerity and thanks to the Deanship of Studies \& Scientific Research (Dr. Adel Ayed Alshammari) at the UHB for supporting this research during the time of data collection.

\section{Conflicts of InTEREST Disclosure}

The authors declare that there is no conflict of interest statement. 


\section{REFERENCES}

[1] AL-Hashimi M. Faculty Perceptions of E-Learning: Case Study. International Journal of Innovative Research \& Development. 2017; 6(4): 211-214.

[2] Al-Asmari A, Rabb-Khan S. E-learning in Saudi Arabia: Past, Present and Future. Middle Eastern Journal of Research in Education. 2014; 2: 1-11. https://doi.org/10.5339/nmejre.2014.2

[3] Aparicio M, Bacao F, Oliveira T. An e-learning theoretical framework. Journal of Educational Technology \& Society. 2016; 19(1): 292-307.

[4] Abdel-Gawad A, Al-Masaud K. Impediments of Activating ELearning in Higher Education Institutions in Saudi Arabia Case Study: Ar-Rass College of Science and Arts, Qassim University. International Journal of Advanced Computer Science and Applications. 2014; 5(4): 12-18.

[5] Altun A, Gulbahar Y, Madran O. Use of a content management system for blended learning: perceptions of pre-service teachers. Turkish Online Journal of Distance Education. 2008; 9(4): 138-153.

[6] Hussein H. Attitudes of Saudi Universities Faculty Members towards Using Learning Management System. The Turkish Online Journal of Educational Technology. 2011; 10(2): 43-53.

[7] Alghamdi S, Bayaga A. Use and attitude towards Learning Management Systems (LMS) in Saudi Arabian universities. Eurasia Journal of Mathematics, Science \& Technology Education. 2016; 12(9): 2309-2330.

[8] West R, Waddoups G, Graham C. Understanding the experiences of instructors as they adopt a course management system. Educational Technology Research and Development. 2007; 55(1): 1-26. https://doi.org/10.1007/s11423-006-9018-1

[9] Mohsen M, Shafeeq C. P. EFL Teachers' Perceptions on Blackboard Applications. Canadian Center of Science and Education. 2014; 7(11): 108-118.

[10] Barhoumi W, AlKhassawneh H. Hail University Learners' Attitudes towards Blended Learning (BL). Journal of Scientific and Engineering Research. 2017; 4(4): 1-6.

[11] Cheok M, Wong S, Ayub A, et al. Teachers' Perceptions of ELearning in Malaysian Secondary Schools. Malaysian Online Journal of Educational Technology (MOJET). 2017; 5(2): 20-33.

[12] Pusuluri S, Mahasneh A, Monawer B. The Application of Blackboard in the English Courses at Al Jouf University: Perceptions of Students. Theory and Practice in Language Studies. 2017; 7(2): 106-111. https://doi.org/10.17507/tpls.0702.03

[13] Alhussain T. Measuring the Impact of the Blackboard System on Blended Learning Students. (IJACSA) International Journal of Advanced Computer Science and Applications. 2017; 8(3): 297-301.

[14] Heirdsfield A, Walker S, Tambyah M, et al. Blackboard As An Online Learning Environment: What Do Teacher Education Students And Staff Think? Australian Journal of Teacher Education. 2011; 36(7): $1-16$.

[15] Grobgeld E, Teichman-Weinberg A, Wasserman E, et al. Role Perception among Faculty Members at Teacher Education Colleges. Australian Journal of Teacher Education. 2016; 41(5): 78-98. https : //doi.org/10.14221/ajte.2016v41n5.6

[16] Asiri M, Mahmud R, Ayub A, et al. Factors Influencing the Use of Learning Management System in Saudi Arabian Higher Education: A Theoretical Framework. Canadian Center of Science and Education Higher Education Studies. 2012; 2(2): 125-137.

[17] Christie M, Jurado R. Barriers to innovation in online pedagogy. European Journal of Engineering Education. 2009; 34(3).

[18] Al Meajel T, Sharadgah T. Barriers to Using the Blackboard System in Teaching and Learning: Faculty Perceptions. Technology, Knowledge and Learning. 2017; 23(2): 351-366.

[19] Zaki H, El Zawaidy H. Using Blackboard in Online Learning at Saudi Universities: Faculty Members Perceptions and Existing Obstacles. International Interdisciplinary Journal of Education. 2014; 3(7): 142-150.

[20] Bradford P, Porciello M, Balkon N, et al. The Blackboard Learning System. Journal of Educational Technology Systems. 2007; 35 : 301-314. https://doi.org/10.2190/X137-X73L-5261-5656

[21] Guhlin M. Stage a well-designed Saturday session and they will come! Technology Connection. 1996 May; 3(3): 13-14.

[22] Al-Naibi S, Madarsha K, Ismail N. Blackboard Use by Faculty Members in the Colleges of Applied Sciences in the Sultanate of Oman. International Journal for Innovation Education and Research. 2015; 3(4): $26-40$

[23] Al-Senaidi S, Lin L. Poirot J. Barriers to adopting technology for teaching and learning in Oman. Computers \& Education. 2009; 53: 575-590. https ://doi .org/10.1016/j.compedu.2009.03.01 